DOI: https://doi.org/10.18371/fp.4(44).2021.889810

УДК 001:891.3:378.4

\title{
ГЕНЕЗИС ПІДХОДІВ ДО ПОНЯТЬ «МОДЕЛЬ» ТА «ЕКОНОМІЧНА МОДЕЛЬ»
}

\author{
ЮРЧИШЕНА Людмила Вікторівна \\ кандидат економічних наук, дочент, \\ доцент кафедри фінансів і банківської справи \\ Донеиького національного університету імені Василя Стуса \\ ORCID ID: https://orcid.org/0000-0002-5904-0758
}

\begin{abstract}
Анотація. $У$ статті досліджено $і$ систематизовано теоретичні підходи до поняття «модель», визначено сфери застосування, тендениії популяризації даного поняття, обтрунтовано призначення моделі відповідно до ї̈ ролі. Здійснено синтез підходів до поняття «економічна модель», виокремлено основні вимоги до ї̈ побудови. Обтрунтовано доцільність впровадження та сутність поняття «економічна модель університету». дель,

Ключові слова: модель, економічна моуніверситет.
\end{abstract}

Постановка проблеми. Поняття «модель» займає визначальне місце в наукових дослідженнях. Моделі дають можливість візуалізувати певні явища, процеси, поведінкові аспекти, управлінські рішення, прогнози тощо. Спектр застосування терміну «модель» $є$ досить багатогранним, як відносно сфер застосування, так і представлення, вони можуть бути простими та зрозумілими для сприйняття, або представляти складні конструкції процесів із набором конкретних інструментів, що притаманні конкретній моделі. Моделі дають можливість ло-
Аннотация. $B$ cmaтье исследованы и систематизированы теоретические подходы к понятию «модель», определены сфреры применения, тенденщии популяризации данного понятия, обосновань назначения модели в соответствии с ее ролью. Осуществлен синтез подходов к понятию «экономическая модель», выделены основные требования $к$ ее построению. Обоснована иелесообразность внедрения и сущность понятия «экономическая модель университета».

Ключевые слова: модель, экономичная модель, университет.

гічно поєднати теорію та практику, часто представляють певну структуру, а його складові візуалізують об'єкти, процеси, відносини тощо. Використання моделей в різних сферах наукових досліджень обумовлено їх маніпулювання задля отримання релевантних результатів, пояснення існуючих і формування нових теорій, гіпотез, концепції тощо.

Широкий спектр застосування моделей обумовлює невизначеність щодо трактування сутності «модель», нерозуміння відмінностей між поняттям «модель» і «економічна модель», що 
обумовлює актуальність і проблематику дослідження.

Аналіз останніх досліджень та публікацій. Сучасні дослідження вітчизняних та іноземних науковців тісно пов'язані 3 проблемою формування моделей, проте їх погляди на дане поняття $є$ досить обмеженими і стосуються розробки моделей для конкретного об'єкта дослідження. На основі синтезу підходів до поняття «модель» можна виділити певні напрямки дослідження, так V.A. Shtoff, I.M. Кульчицький, К.Б. Батароєва, О. Мороз досліджують модель як систему, О.Ю. Смерічко, М.В. Грібанов, Л.М. Фрідман співставляють модель 3 уявним або умовним образом, якому притаманні певні риси, властивості, взаємозв'язки, J. Woodward визначає модель як інструмент визначення причинно-наслідкових зв'язків.

Дослідження економічної моделі висвітлені в працях іноземних науковців, таких як R. Kanolkar, S. Ouliaris, D. Rodrik, A. Jacalyn, B. Shea, X. Gabaix, D. Laibson та інших. Проблематика формування економічної моделі університетів представлені в працях Л. С. Шевченко, Л.В. Юрчишена, A. Jacalyn, B. Shea, а також дослідженнях щодо формування університетів в майбутньому. Проте, для розуміння сутнісного наповнення поняття «модель», «економічна модель», «економічна модель університету» доцільно дослідити і систематизувати підходи до їх визначення.

Метою статті $\epsilon$ синтез теоретичних підходів до поняття «модель», визначення тенденцій популяризації даного поняття та широти використання під час досліджень, призначення моделі, дослідження сутності поняття «економічна модель» та обгрунтування доці- льності іiі впровадження в університеTax.

Виклад основного матеріалу дослідження. Поняття «модель» досить багатогранне і використовується в різних галузях знань, набуваючи специфічного змісту та вирізняючись складністю представлення. На рис. 1 представлено 50 напрямків досліджень за ключовими словами «модель».

Результати пошуку на публічному pecypci Lens.org за 1980-2021 pp. показали, що більше 19 млн публікацій пов'язані 3 дослідженням моделей. Найбільше поняття «модель» зустрічається в комп'ютерних науках в більше 3 млн публікацій, медицині більше 2 млн, біології - 1,5 млн, фізиці - 1,5 млн, інженерії - 1,4 млн, хімії - 1,4 млн, математичних науках 1,2 млн, філософії - 0,9 млн, економіці - 0,7 млн, бізнесі - 0,6 млн щодо інших наук, то даний термін не $\epsilon$ таким розповсюдженим.

Оцінюючи популяризацію терміну «модель» в динаміці (рис. 2) спостерігається значний приріст публікацій починаючи з 2000 р. - 271 тис., в порівнянні $з 1980$ р. - 54 тис., з 2006 р. більше 0,5 млн публікацій у різних галузях були пов'язані $з$ дослідженням моделей різних типів, в 2020 р. кількість публікацій перевищила 1,5 млн.

Поняття «модель» дає розуміння про об'єкт, явища із притаманною їм структурою, властивостями, зовнішніми і внутрішніми процесами взаємодії, проте система наукових поглядів щодо даного поняття зводиться до створення об'єктів-репрезентантів, за допомогою яких апробуються наукові дослідження.

Моделі можуть імітувати певне явище, об'єкт, систему з притаманними причинно-наслідковими зв'язками, 


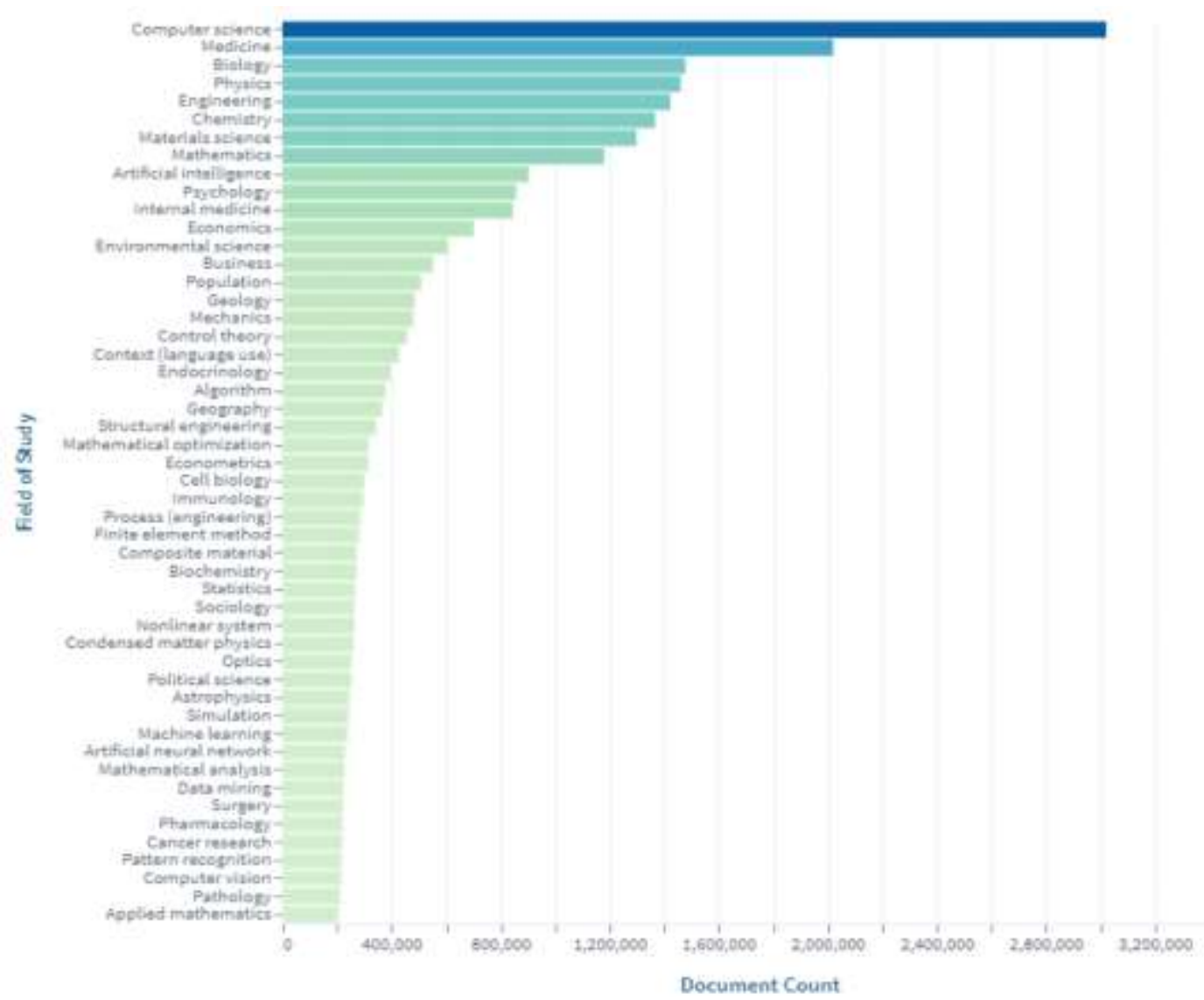

Рис. 1. Напрямки дослідження, де вживається термін «модель» Джерело: складено автором на основі[1]

за допомогою моделей можна отри- вана модель, вона містити методомувати результати або аналітично логічне підгрунтя та $\epsilon$ об'єктом розв'язувати математичні алгоритми. маніпулювання для отримання Проте незалежно від того, як побудо- об’єктивних результатів дослідження.

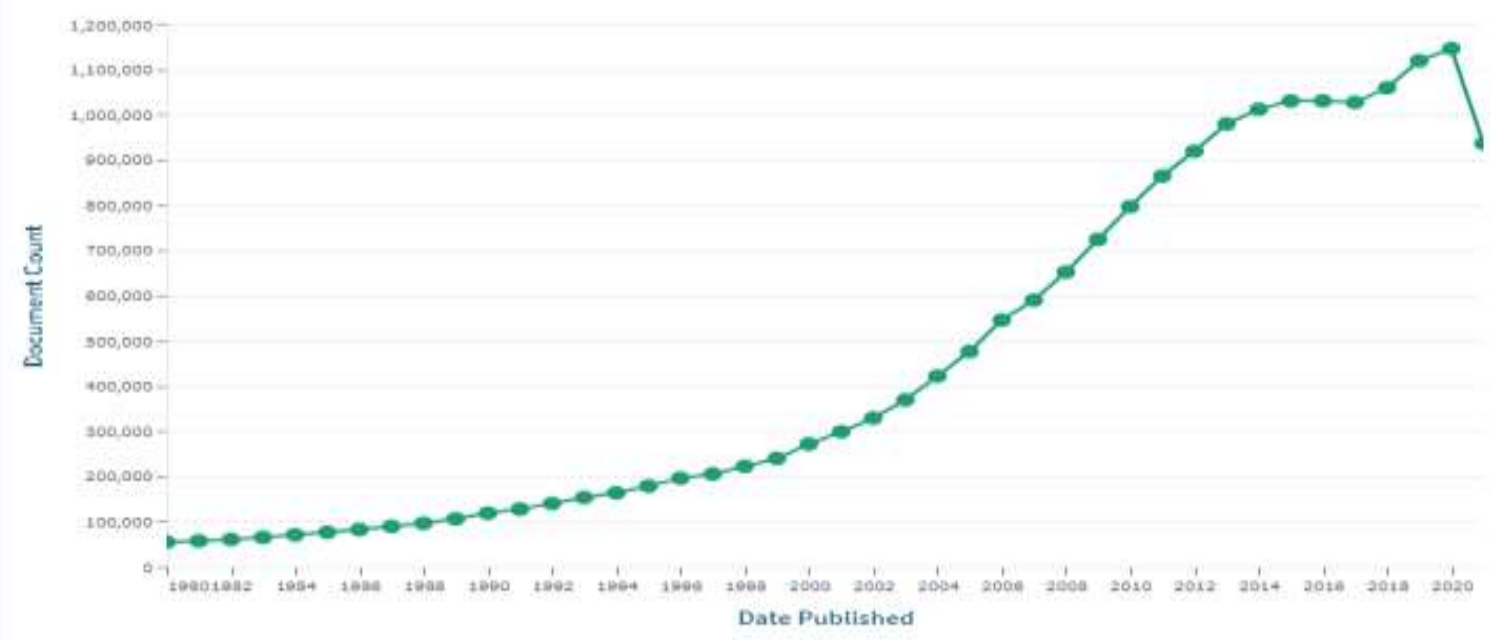

Рис. 2. Динаміка досліджень пов'язаних з поняттям «модель» Дюерело: складено автором на основі [1]

Моделі розробляються для аналізу, набір інструментів за допомогою яких пояснення або прогнозування до- можна пояснити прогнозований ресліджуваного явища, вони включають зультат змодельованої ситуації, пе- 
ревірити іiі адекватність, і прийняти правильні управлінські рішення.

В наукових контекстах поняття «модель» набуває різного значення, так філософи досліджуючи процеси, проблеми, оформлюють иї як результат у вигляді певного типу моделей (моделі розвитку, теоретичні моделі, пояснювальні моделі, дослідницькі моделі, дидактичні моделі, уявні, математичні, інструментальні тощо); семантика розглядає моделі як репрезентанта, що представляє цільову систему; онтологія як вчення про буття, досліджує типи моделей; гносеологія, як теорія пізнання і дає відповідь на питання: «Як ми вчимося та пояснюємо за допомогою моделей» [2].

Підходи до поняття «модель» різняться, проте можна виділити найбільш поширені:

1. Модель як система (системарепрезентант, абстрактна система тощо). Ототожнення моделі як системи передбачає, що будь-яка інформація про об'єкт повинна бути перетворена у знання про цільову систему, проте залежно від типу моделі передача інформації різниться. Модель відкрита система, пов'язана із зовнішніми економічними, соціальними, політичними та природними умовами [2, с. 158].

Так, В. А. Штофф визначає модель, як умовно подану чи матеріально реалізовану систему, яка відображає або відтворює об'єкт дослідження, здатну заміщати його так, що їі вивчення дає нову інформацію про цей об'єкт [4].

I. М. Кульчицький [5, с. 280] визначає модель, як систему-репрезентант, аналіз якої слугує способом отримання інформації про іншу систему.

На думку К. Б. Батароєва [6], модель - це створена або вибрана суб'єктом система, яка відтворює істотні для об'єкта дослідження елементи, властивості, відносини, параметри, знаходиться 3 ним у відносинах заміщення, схожості (ізоморфізму), а iii дослідження служать опосередкованим способом отримання знання про цей об'єкт.

О. Мороз [7, с. 391] досліджує модель, як предметну, знакову чи уявну систему, що відтворює, імітує чи відображає певні суттєві характеристики, принципи внутрішньої організації або функціювання, властивості чи ознаки об'єкта пізнання (оригіналу), безпосереднє вивчення якого з певних причин неможливе, неефективне або недоцільне, і може замінити цей об'єкт у процесі дослідження 3 метою отримання знань про нього.

2. Модель як уявний чи умовний образ або об'єкт із притаманними характеристиками, властивостями $i$ взаємозв'язками. Даний підхід до визначення сутності поняття «модель» $\epsilon$ досить поширеним, так О. Ю. Червак-Смерічко здійснюючи дослідження математичного моделювання в економіці визначає, що «модель - представлення, вироблене в уяві людинидослідника, про ті чи інші властивості об’єкту (реального, абстрактного) і їх взаємозв'язки, оформлене у вигляді описання цього об'єкту і зафіксоване на папері мовою рисунка, графіка, рівняння, формул, тощо, або представлене у вигляді макетів, механізмів, пристроїв, тощо» [8]. В соціологічній енциклопедії [9] визначено, що модель (лат. modulus - міра, зразок) є узагальнений синтезований образ об'єкту прототипу (явища, процесу), що використовується для вивчення, дослідження, систематизації тощо. 
Такого ж підходу дотримуються інші науковці, так М. В. Грібанова [10] досліджує модель як об'єкт, призначений не тільки для вивчення наявних i потенційних можливостей предмета пізнання, а також як образ бажаного, потрібного в реальному втіленні.

Л. М. Фрідман [11] стверджує, що модель $\epsilon$ реалістичною, і визначає деякий об'єкт (систему), дослідження якого є засобом для одержання знань про інший об'єкт (оригінал).

Чітке ототожнення моделі як об'єкта прослідковується у трактуванні Мороза О. [7, с. 391], який визначає модель (від лат. modus - міра) у загальному розумінні як аналог (графік, схема, знакова система, структура) певного об'єкта (оригі-налу), фрагментарна реальність, артефакт, витвір культури, концептуально-теоретичні утворення тощо. Модель - об'єкт, який має схожість в деяких відносинах 3 прототипом і слугує засобом опису i/aбо поясненням, i/або прогнозуванням поведінки прототипу [12, с. 349].

3. Модель як інструмент визначення причинно-наслідкових зв'язків, досліджено в працях Woodward James [13], який доводить, що вони існують між певними фактами чи процесами, $\mathrm{i}$ виконують пояснювальну роботу щодо визначення закономірностей, протилежних залежностей, і дозволяють виявити, пояснити різницю за різних умов функціонування під дією різних факторів.

Розробка моделі здійснюється для досягнення певного результату, тобто поставленої мети, залежно від якої визначається ступінь складності, реалістичності, наукової обгрунтованості, чим i різниться роль або процес участі - від аналітичного, прогнозуючого, дослідницького, пояснювального інструментів до інтеграції міждисциплінарних досліджень, в рамках яких визначається призначення відповідної моделі [14] (рис. 3).

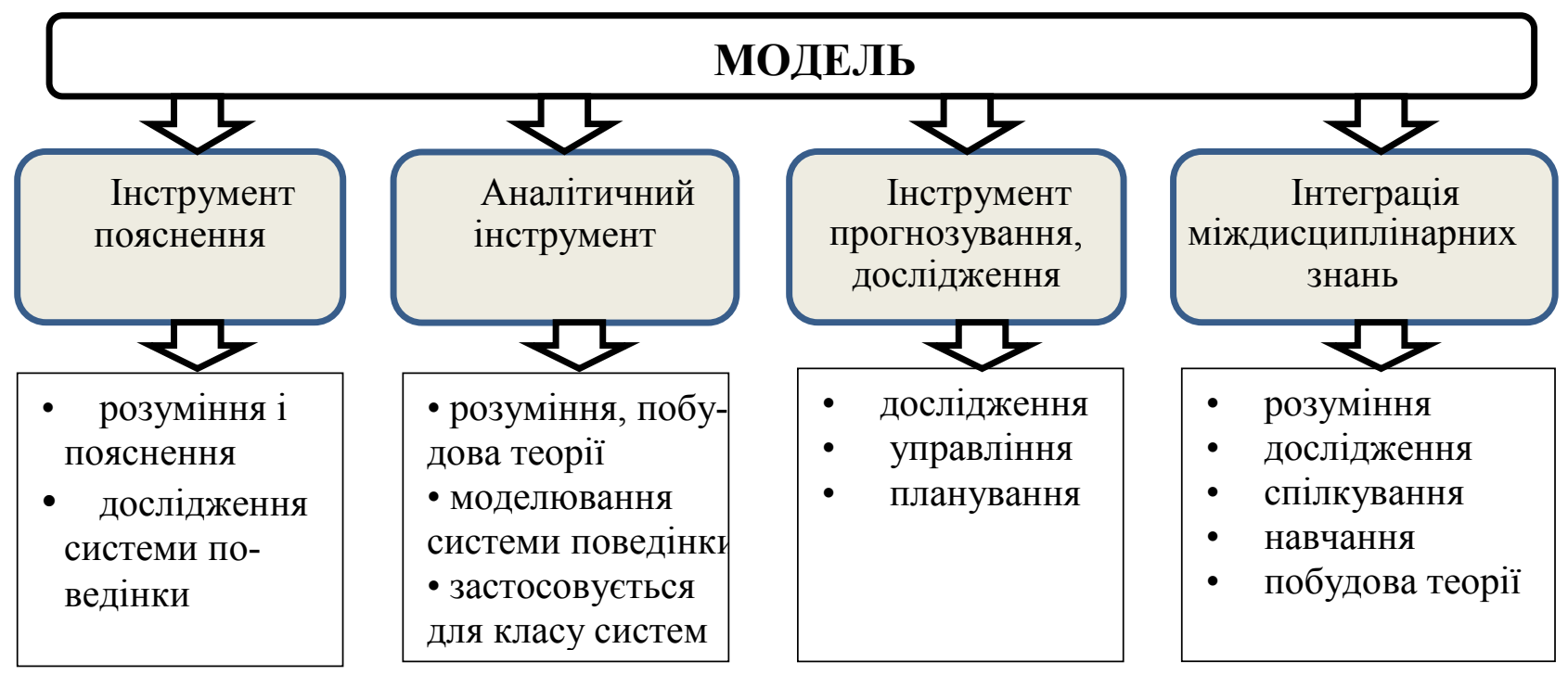

Рис. 3. Призначення моделі відповідно до іiі ролі Джерело: складено автором на основі [14] 


\section{Модель дає можливість:}

- зрозуміти, як влаштований конкретний об'єкт, яка його структура, властивості, закони розвитку i взаємодія із зовнішнім середовищем;

- приймати управлінські рішення щодо об'єкту (процесу, явища) управління за заданих цілей, параметрів, обмежень, критеріїв;

прогнозувати прямі і непрямі наслідки реалізації заданих способів і форм впливу на об'єкт.

Використання науковцями терміну «модель» в різних галузях знань зумовлює неоднозначність трактування даного поняття, множинність варіацій побудови моделей від простих до складних, проте основне їх призначення - це пояснення, засноване на ідеалізованій моделі, яке залишає лише ті особливості, які не мають значення для відповідного пояснювального завдання.

Економічна модель розглядається як теоретична конструкція, яка включає набір припущень, складових, що логічно взаємов'язані між собою, дають змогу змоделювати економічну ситуацію, виявити причиннонаслідкові зв'язки між елементами моделі. Економічна модель розробляється $з$ метою оцінки ефективності різних альтернативних варіантів розвитку подій в майбутньому, є поширеним способом аналізу і прогнозування економічної ситуації як на рівні окремого суб'єкта господарювання, так і на рівні держави.

Досліджуючи економічну модель Rucha Kanolkar [15] розглядає іiї як організовану сукупність відносин, яка описує функціонування економічної ідентичності за набором припущень, за результатами яких формуються висновки. Sam Ouliaris [16] визначає економічну модель як спрощений опис реальності, призначений для висунення гіпотез про економічну поведінку, які можна перевірити.

Економічні моделі дають можливість пояснити вплив явищ, що досліджуються в реальності на результат, проте незалежно від рівня складності вони $є$ наближеними до реальності, адже жодна модель не може бути ідеальною, особливо в умовах динамічно мінливих умов об'єкта дослідження. Економічні моделі складаються 3 чітко сформульованих припущень та поведінкових механізмів, ізольованих від інших систем, діють символічно використовуючи слова i математику [17, с. 22].

Науковці розрізняють два класи економічних моделей:

теоретичні, за допомогою яких можна перевірити наслідки економічної поведінки, роблячи певні припущення щодо того, що агенти максимізують цілі 3 урахуванням існуючих обмежень, які чітко визначені в моделі, дають якісні відповіді на питання «що буде, якщо?»;

емпіричні застосовуються для перевірки якісних прогнозів теоретичних моделей, переносячи їх на точні числові результати, наприклад, як зміняться витрати при зростанні доходів університету [16].

Економічна модель проходить постійний процес трансформації, i включає: фінансове середовище, місію та ціннісну пропозицію, організаційну структуру і прийняття рішень, інституційні компетенції та процеси $[18$, c.6].

Побудова економічної моделі включає ряд етапів: відбір змінних моделі, 
прийняття припущень, виділення гіпотез, що пояснюють взаємозв'язки параметрів моделі. Реалізація даних етапів потребує дотримання певних умов при їі розробці: змістовність, реалістичність припущень, що ставляться в моделі, можливість прогнозування, достатнє інформаційне забезпечення, можливість перевірки на практиці [19]. Успішним економічним моделям властиві такі ознаки, як: ощадливість, платоспроможність, концептуальність, узагальненість, спростовуваність, емпірична послідовність, прогнозована точність [20, с. 9].

Отже, можна виокремити основні вимоги до побудови економічних моделей: адекватність, гнучкість, раціональність, динамічна послідовність, інформаційність, економічна доцільність.

Економічна модель університету прагматика того як трансформує ресурси університет у нові активи i можливості, i включає фінансування та бізнес-модель [21, с. 11].

За результатами дослідження Шевченко Л.С. нова модель економічної діяльності ЗВО базується на реалізації права університетів на економічну самостійність, здатності генерувати власні (позабюджетні) доходи, збільшувати частку приватних джерел фінансування [22].

В 2014 р. фінансова стійкість коледжів та університетів США визначалася дією зовнішніх та внутрішніх факторів, що було обумовлено скороченням державного фінансування, зміною демографічних показників, зменшенням цінності вищої освіти, і стало передумовою прийняття рішення Радою директорів NACUBO (National Association of College and University Business Officers) щодо вивчен- ня існуючих та пошуком нових бізнесмоделей.

За результатами дослідження NACUBO [23] економічна модель освіти має чотири основні виміри:

- фінансове середовище;

- інституційна місія та ціннісна пропозиція;

- організаційна структура та система прийняття рішень;

- інституційні компетенції і процеси.

Економічна модель університету та його фінансова стійкість є результатом прийнятих рішень про місію, структуру, сильні сторони та ресурси. Це результат усіх видів діяльності та функцій, вхідних та вихідних даних закладу [23]. Економічна модель, згідно проєкту NACUBO, включає чотири ключові сфери: місію, структуру, сильні сторони і ресурси [23] (рис.4).

Така економічна модель визначає місце університету в майбутньому, шляхом формування місії i бачення його розвитку. Місія формується 3 урахуванням поточного стану, статусу, можливостей, структури закладу, визначення його сильних та слабких сторін, ресурсів, які можна залучити i використати для досягнення стратегічних пріоритетів розвитку. Структура університету розглядається як внутрішньо-організаційна складова, що визначає ролі та відповідальність за надання продуктів та послуг, та міжорганізаційна - показує механізми, що створені для використання ресурсів та компетенції. Структура університетів в економічній моделі може бути різна, залежно від розвиненої мережі партнерів, диференціації освітніх послуг, оптимізації підрозділів закладу 3 метою зменшення витрат на їх забезпечення та управління. 


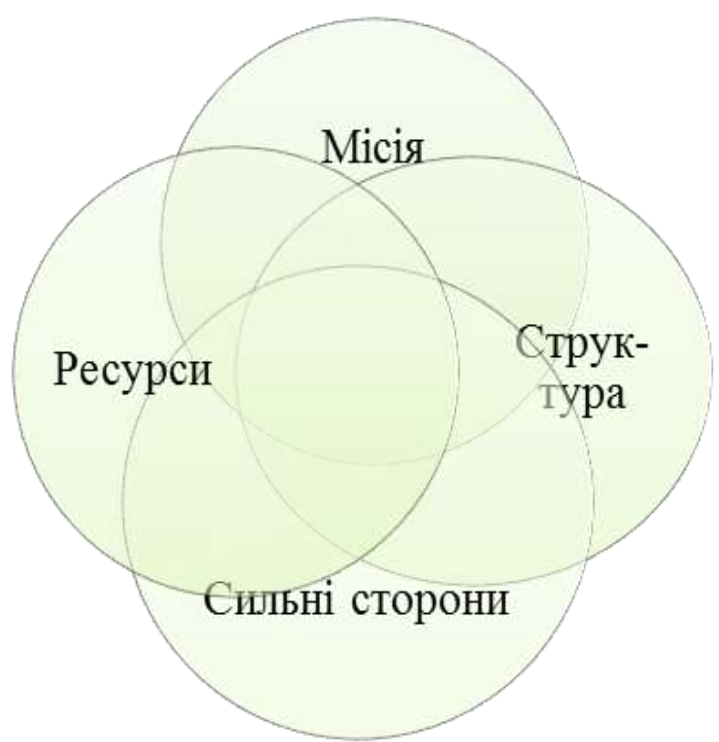

Рис. 4. Економічна модель університету згідно проєкту NACUBO Джерело: [23]

В міжнародній практиці існують нетрадиційні структури, наприклад, Консорціум Університету Клермонт об'єднав численні коледжі та університети для спільної реалізації та обслуговування освітніх програм. Нові підходи до формування структури університетів визначають, що однією iз головних складових $\epsilon$ лідерство, адже саме лідери є агентами змін, новаторами, які впроваджують інноваційні напрямки розвитку установи.

Сильні сторони в економічній моделі розглядаються як компетентність працівників закладу виконувати певні дії задля реалізації місії. Наявність значного потенціалу кваліфікованих кадрів - один із інструментів фінансової стійкості, адже якісна реалізація освітніх послуг популяризує університет, збільшує попит на освітні послуг, і як наслідок заклад отримує додаткове фінансування. Компетентні викладачі здатні приймати участь у наукових дослідженнях, експериментах, проєктах, отримувати гранти, впроваджувати нові і реформувати існуючі освітні програми, що є додатковими джерелами фінансування університету [23].

Ресурсна складова економічної моделі забезпечує надходження фінансових ресурсів для формування як матеріальних, так і нематеріальних активів. Критичним для економічної стійкості є узгодження стратегії залучення та використання ресурсів, що повинні відповідати місії та цілям університету. Проте не всі структурні підрозділи університету можуть оптимально використовувати ресурси, за умови запровадження процесів бюджетування або якщо планування та складання бюджетів не інтегровані [23].

Світовий досвід показує, що сучасні інструменти бюджетування та планування набувають все більшого поширення в університетах, оскільки узгоджують ресурси 3 програмами та діяльністю, що їх генерують. Ще одним інструментом, який набув практичного використання у вищій школі, є калькуляція витрат, що застосовується для аналізу диференціації витрат між дисциплінами та способами навчання, освітніми програмами тощо. 
Формування капіталу та людських ресурсів потребують стратегічного бачення $з$ боку керівництва університету, адже в більшій мірі формують довгострокові зобов’язання перед науково-педагогічним персоналом через укладання середньо та довгострокових контрактів. Тому, використання фінансових інструментів в університетах дає можливість оцінювати можливості, окреслювати фінансові перспективи та активно шукати додаткові джерела залучення фінансових ресурсів.

Вагомим драйвером фінансування $\epsilon$ вартість навчання у закладах вищої освіти, проте вона досить диференційована, до 2020 року в Україні значна частка 3ВО демпінгували, тим самим використовуючи інструменти цінової конкурентної боротьби за здобувача вищої освіти. Створюючи попит на дешеві освітні послуги серед неплатоспроможного населення, ЗВО часто приховувало «підводні камені» щодо оплати додаткових послуг впродовж навчання. Здобувачі готові платити високу вартість за якісне навчання в престижних університетах.

Діяльність університетів перебуває в процесі трансформації, що обумовлено драйверами трьох рівнів: глобальні, національні та локальні. Задля підтримання конкурентних позицій Університети повинні створювати ціннісні пропозиції, а це потребує запровадження економічних моделей. Тому, саме економічні моделі $\epsilon$ iнструментом прийняття управлінських рішень університетським менеджментом. Побудова економічних моделей в університетах може мати різну інтерпретацію, проте, найбільш ефективними, на нашу думку є ті, що базуються на ціннісному підході, враховують запити стейкхолдерів, містять логічний набір компонентів (ресурси, процеси, технології тощо) задля досягнення поточних і стратегічних цілей університету [24].

Висновки. Результатом дослідження $є$ синтез підходів до поняття «модель», і обгрунтування іï як системи (репрезентанта, абстрактної тощо), як уявного чи умовного образу, як інструменту визначення причиннонаслідкових зв'язків. Залежно від сфери застосування модель може використовуватися як інструмент пояснення, аналізу, прогнозування, дослідження, інтеграції міждисциплінарних знань.

Досліджено сутність поняття «економічна модель», іiі типи, особливості побудови, в результаті чого обгрунтовано поняття «економічна модель університету», що формує концептуальний рівень іiі сприйняття, представляє теоретичну конструкцію логічно взаємопов'язаних компонентів, формує певні припущення, гіпотези про економічну поведінку суб'єкта внаслідок виникнення причинно-наслідкових взаємозв'язків, що впливають на економічні результати діяльності закладу. Поняття «економічна модель університету» $\epsilon$ відносно новим і потребує подальшого дослідження, як в контексті змістовного наповнення, так i практичного впровадження в університетах на основі їх типологізації.

\section{Список використаної літератури}

1. Search, Analyze and Manage Patent and Scholarly Data. URL: https://www.lens.org (дата звернення: 07.12.2021). 
2. Frigg Roman and Stephan Hartmann, «Models in Science», The Stanford Encyclopedia of Philosophy (Spring 2020 Edition), Edward N. Zalta (ed.), URL: https://plato.stanford.edu/entries/models-science/\#SemaModeRepr (дата звернення: 10.10.2021).

3. Економічна ефективність vs соціальна справедливість: пріоритети розвитку України на етапі подолання кризи: кол. моногр. НАН України, Секція суспільних і гуманітарних наук. Київ, 2019. 350 с.

4. Штофф В.А. Моделирование и философия. Москва: Л.: Наука, 1966. 320 с.

5. Кульчицький I. М. Концептуалізація понять «модель та моделювання» у наукових дослідженнях. Вісник Національного університету Львівська політехніка. Інформаційні системи та мережі. 2015. № 829. С. 273-284.

6. Батароев К.Б. Аналогии и модели в познании. Новосибирск: Наука, 1981. C. 320 .

7. Мороз О. Модель. Філософський енциклопедичний словник. Київ: Інститут філософії імені Григорія Сковороди НАН України : Абрис, 2002. $742 \mathrm{c}$.

8. Червак-Смерічко О. Ю. Математичне моделювання в економіці: моделювання і системний аналіз. Науковий вісник Ужгородського національного університету. Серія: Економіка. 2015. № 2. С. 246-254.

9. Городяненко В. Г. Соціологічна енциклопедія. Київ: Академвидав, 2008. $456 \mathrm{c}$.

10. Грибанова М. В. Моделирование в образовании. Пермь: Перм. гос. пед. ун-т., 1999. 45 с.

11. Friedman M. Explanation and scientific understanding. The Journal of Philosophy. 1974. № 71(1), C. 5-19. doi:10.2307/2024924.

12. Анфилатов В. С., Емельянов А. А., Кукушкин А. А. Системный анализ в управлении: учеб. пособие. Москва. Финансы и статистика, 2002. 368.

13. Woodward J. Making things happen: A theory of causal explanation. Oxford university press. 2005. doi: 10.1093 / 0195155270.001 .0001$.

14. Schlüter M., Müller B., Frank K. The potential of models and modeling for socialecological systems research: The reference frame ModSES. Ecology and Society, 2019. № 24 (1):31. doi:10.2307/26796919.

15. Rucha Kanolkar. Essay on Economic Models. URL: https://www.economicsdiscussion.net/essays/economics/essay-on-economicmodels/17679 (дата звернення: 08.11.2021).

16. Ouliaris S. What are economic models. Finance \& Development. 2011. № 48 (2). 46-47.

URl: https://www.imf.org/external/pubs/ft/fandd/2011/06/basics.htm (дата звернення: 06.11.2021).

17. Rodrik D. Economics rules: The rights and wrongs of the dismal science. WW Norton \& Company, 2015. C. 253.

18. Jacalyn A., Shea B. Possible futures for higher Education's economic model, 2016. C. 26. 
19. Малахов А. Для чего нужны экономические модели. 2014. URL: https://blog.in-vesto.ru/macroeconimics/dlya-chego-nuzhny-ekonomicheskiemodeli.html (дата звернення: 25.10.2021).

20. Gabaix X, Laibson D, Caplin A, Schotter A. The Seven Properties of Good Models. The Methodologies of Modern Economics: Foundations of Positive and Normative Economics. Oxford University Press; 2008

21. Майбутнє університетів: еволюція університетів: на порозі невідомого майбутнього. URL: https://www.slideshare.net/UIFuture/ss-126507553 (дата звернення: 12.09.2021).

22. Шевченко Л. С. Нова модель економічної діяльності чи приватизація університетів? Фінансово-кредитна діяльність: проблеми теорії та практики. 2018. T. 3. № 26. C. 516-522.

23. The NACUBO Economic Models Project Journey: URL: http://emp.nacubo.org/_(дата звернення: 20.09.2021).

24. Юрчишена Л. В. Формування нової парадигми вищої освіти: драйвери та економічна модель університетів. Економіка і організація управління. 2021. №2 (42). C. 142-152. doi: https://doi.org/10.31558/2307-2318.2021.2.14. 